RECEIVED:

20 July 2021

ACCEPTED:

20 August 2021

RELEASED:

20 October 2021
UDC 336.781.2:336.762(594)

DOI 10.26661/2522-1566/2021-3/17-03

\title{
INTEGRATED CONTACT CENTER HAI (HELP, ANSWER, IMPROVE) AS INFORMATION SERVICE INNOVATION AT THE MINISTRY OF FINANCE, INDONESIA
}

\author{
Erys Al Fauzi Minhando \\ Universitas Sebelas Maret \\ Surakarta, Central Java, \\ Indonesia \\ ORCID ID: 0000-0003-2567- \\ 2113
}

\author{
Sudarmo \\ Universitas Sebelas Maret \\ Surakarta, Central Java, \\ Indonesia \\ ORCID ID: 0000-0003-0993- \\ 9690
}

\author{
Andre Noevi Rahmanto \\ Universitas Sebelas Maret \\ Surakarta, Central Java, \\ Indonesia \\ ORCID ID: 0000-0001-7331- \\ 4973
}

*Corresponding author email: erys.alfa@student.uns.ac.id

Abstract. Organizational change is unavoidable in the development of an organization. Responding to the dynamics of the environment that continues to change, it is necessary to have a form of innovation in all systems within the organization. Information services are important for the running of an organization. In public sector organizations, user information services are the main demands so that the service process can run well and by the wishes of users. This article aims to identify and describe the information service innovations that exist in the Ministry of Finance. Using qualitative methods with descriptive analysis, this study tries to describe and explain the existence of these policy innovations. this study conducted interviews with leaders connected to Contact Center HAI information service innovations and staff who run these innovation projects. Researchers also observe directly the process of change and innovation of information service systems that exist within the organization so that they can describe in detail the existing innovations. This article has the result of typologies of the information service innovation. There are five types of innovation, namely process innovation, product innovation, method innovation, system innovation, and conceptual innovation. The five innovations provide each progress for improving service performance in Contact Center HAI.

Keywords: policy innovation, communication services, information technology.

JEL classification: L88, O32, O38

\section{INTRODUCTION}

Contact center information services are certainly familiar because they have become popular and become the subject of discussion in meeting information needs by the public. (Park, J. et al, 2011). This need for information makes people no longer hesitate to use the services of information 
providers in every organization. Users use an information service system to make it easier to receive and use the services provided by the organization. Contact center services which grow $8 \%$ annually (Rijo, R. et al, 2012) prove that user information services are indeed very important for organizations. With the development of technology, the communication that is presented through contact center information services is increasingly developing according to customer needs. (Parasuraman and Grewal, 2000). The Ministry of Finance is one of the organizations that continues to develop user information service systems to improve the quality of services provided. Innovation is the key to organizational success as well as public sector organizations which are closely related to the dynamics of public policy in the face of a dynamic environment.

Public policy is one of the focuses of attention not only academics but also the general public who see how the government takes action in solving public problems. In its development, the more public problems develop, the more forms of action taken by the government in the form of policies developed by government officials will develop. (Islamy, 2009). The implementer of the policy is the entire community, both individuals and organizations that are bound by the policy. An organization is a place where a group of people carries out activities with the same goal, namely organizational performance. It becomes a dilemma in itself if the implementation of activities within an organization becomes a different part in various individual views. This different purpose is not different from individual goals but organizational goals that are perceived differently for each member of the organization. So that in the implementation of organizational activities, management is needed so that these activities can run smoothly and by organizational goals.

Policy implementation is an important part of managing a public organization. Public organizations can achieve their goals in serving the public by implementing good service policies. Managing an organization becomes a big challenge when it comes to environmental changes. Organizations must adapt to their environment for them to maintain or increase their effectiveness. So organizations develop monitoring and feedback mechanisms to identify and follow their environment, sense changes in the environment, and make appropriate adjustments when needed (Robbin, 1994). This environmental uncertainty demands that the organization must always be vigilant in various forms of change so that organizational goals can be achieved according to what has been formulated from the start. In line with this, organizing is a thought process that is made possible through communication to reduce uncertainty (Karl Weick, 1979 in Littlejohn, 2010). Good and effective communication can make an organization more open in thinking and develop better. (Soekardi, A., et al, 2020). According to Weick, Organization is not a static arrangement but is inherently composed of dynamic processes of communication. Weick also argues that communication is a basis for human organization and provides a rationale for understanding how humans organize

This uncertainty demands that organizations have to change according to uncertainty both from the environmental, community, and organizational aspects. In organizations, uncertainty is also part of the study in managing organizational change so that an organizational system is needed to achieve the desired form of change. (Robbins, 1994). Likewise, the environment and society must also adjust to the changes that exist so that life can run and be sustainable. Society changes with other changes in the environment. in public institutions, the form of human change in public sector organizations can be described through the ways and forms of public servants serving the community. Bureaucratic reform became an attractive offer for the country which was in the spotlight due to public dissatisfaction with the form of service provided by the state at that time. Changes in public organizations are a necessity to adapt to changes in the environment. Changes are very important in public sector organizations because the environment continues to develop competitively so that there is a need for change management in dealing with the challenges of change that occur (Ziemba \& Oblak, 2015; Kikcert, 2014; Kuipers et al, 2014; Rees et al, 2010; Ningtyas, T. et al, 2020). 
Minhando, E., Sudarmo and Rahmanto, A. (2021), "Integrated contact center HAI (help, answer, improve) as information service innovation at the ministry of finance, Indonesia", Management and entrepreneurship: trends of development, 3(17), pp.27-42. Available at: https://doi.org/10.26661/2522-1566/2021-3/17-03.

Among the basic guidelines of these changes is about improving the quality of service. Reformation changes people in both community organizations and public servants themselves for the better. (Ningtyas. T. et al, 2020). Meanwhile, the scale of reform and restructuring has changed the character and ideological foundations of society so that it is in a transformational form. (Worrall, L. et al, 2000; Osborne and Gaeble, 1992). The transformational changes that occur in changes in public services are sudden and so fundamental (Patrickson, M and Bamber, G, 1995), while according to Welch and Wong (1998) the dimensions that occur in changes in public services are not only local but also on a large scale. Global, because it is a form of global pressure (Welch, 1998). This confirms that there is a transformational change in our government. Sheefani \& Mutingil (2016) also identify and measure that service quality can determine strategies in providing the expected service quality (Sheefini, N., \& Mutingil M, 2016). Efforts to improve the quality of public services are a form of long-term policy as a form of government effort in creating a bureaucracy as expected by the community (Ningtyas, T, 2017). So it is important to pay attention to the quality of services provided by public sector organizations. The existence of a complaint from the community is a sign of how public services must be improved. Figure 1 below is an index of public service complaints in Indonesia.

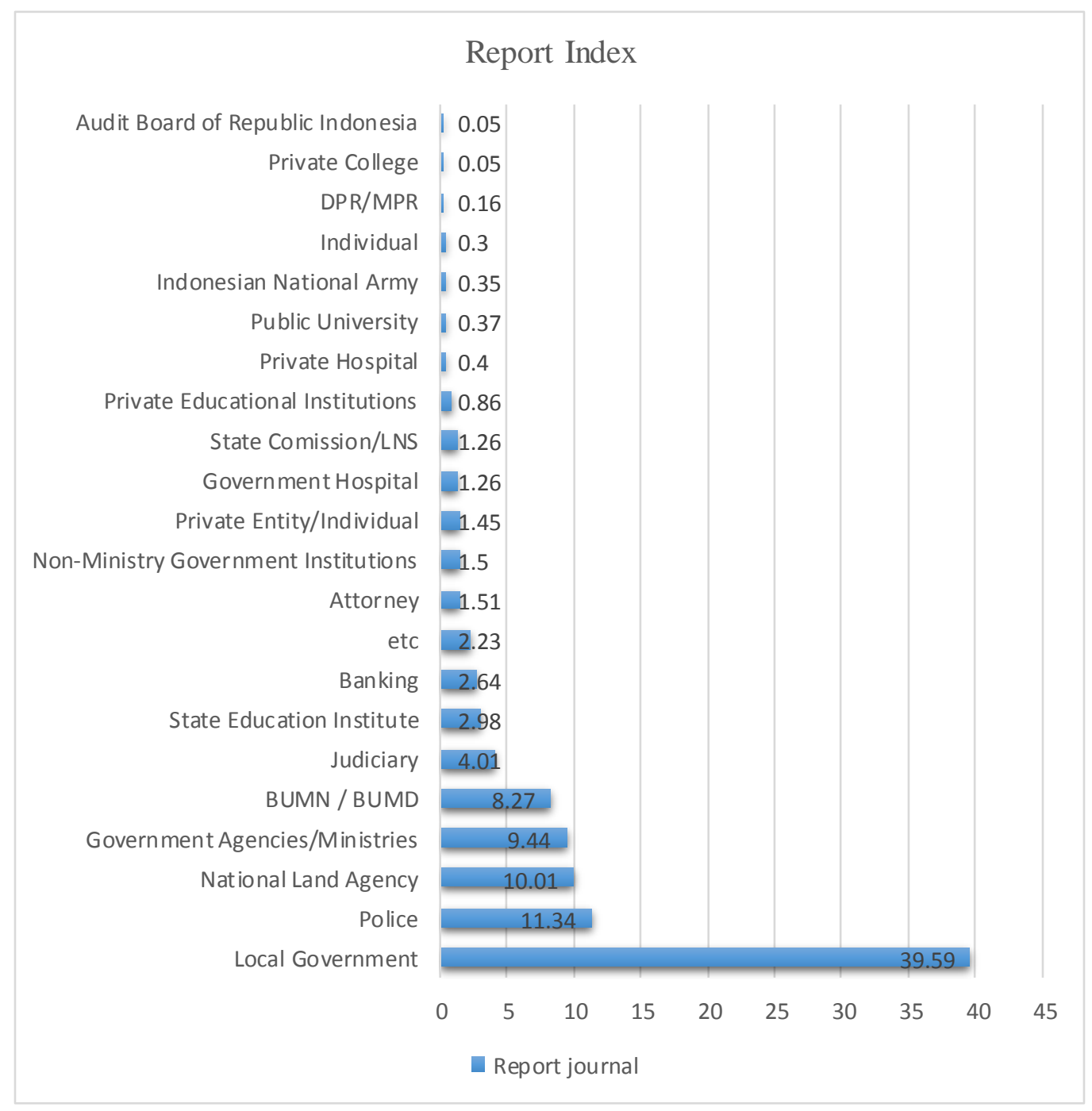

Figure 1 Public Service Complaints Index 2020

Source: Ombudsman, 2020 
Based on the data in Figure 1 above, the highest index of service complaints submitted by the public is related to local government services, the police, the national land agency, government agencies, and BUMN/BUMD. State financial services get a low index, this indicates that the level of public satisfaction is quite high related to the services provided by the unit that handles the state finance sector. Furthermore, in Figure 2, the Progress of Public Complaints Reports on Services for 2016-2020 is presented.

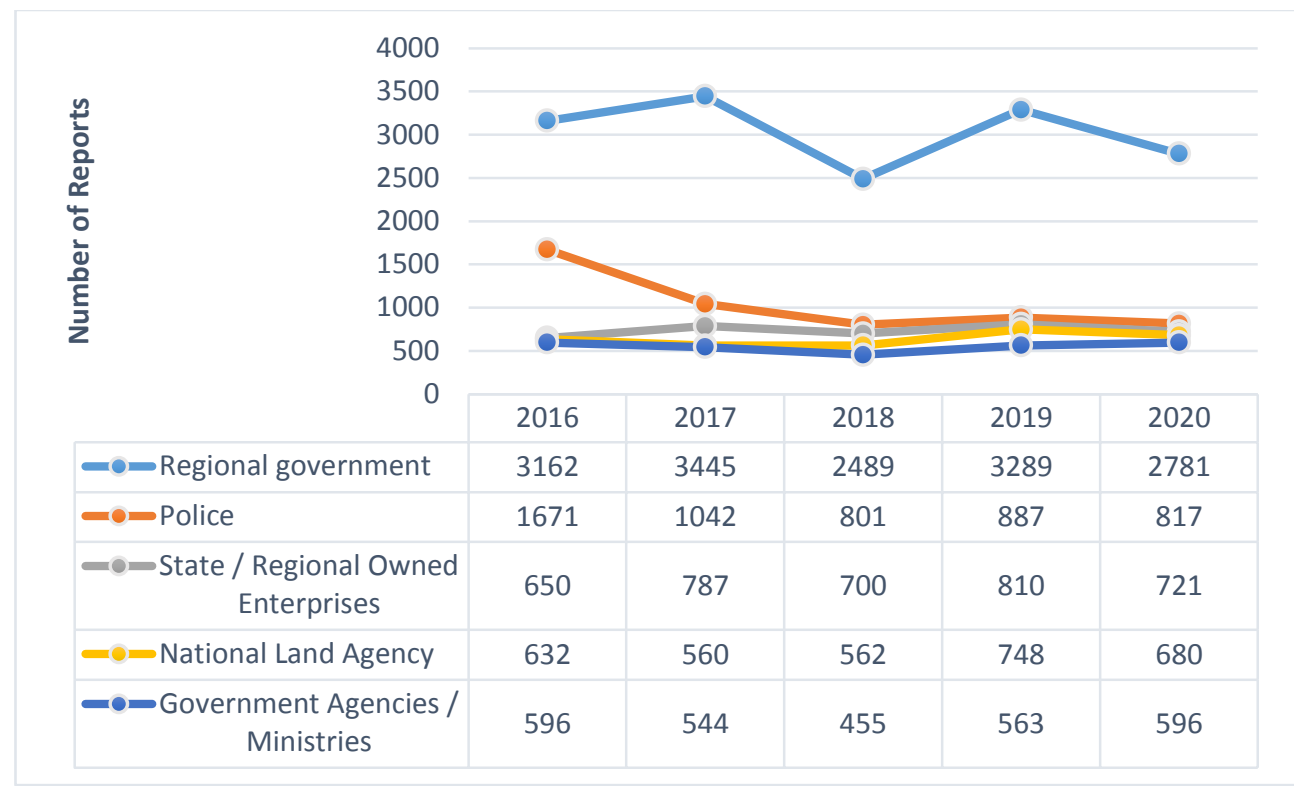

Figure 2 Development of Public Complaints Reports on Services for 2016-2020

Source: RI Ombudsman Annual Report 2016 - 2020

It can be seen in Figure 2 above that Local Government Agencies always occupy the top rank in public complaints. Meanwhile, services provided by Government agencies/Ministries tend to be fewer and stagnant from year to year. This requires organizations to continue to develop themselves to meet the demands of community services during a dynamic environmental change. According to Yeatman, global environmental factors influence the context of changes in public services, besides that the social changes that occurred in society at that time showed that broad social changes had accompanied the agenda of changing public services. (Yeatman, 1994). Talking about changes in public services cannot be separated from the development of information services owned by each unit. Information services as the face of the service of a public organization. Information services continue to grow and are dynamic in line with advances in information technology. Various information technology platforms provide various things that can be used as a means of providing information services for public organizations to all stakeholders. Digitizing public services is one that has been recognized and developed starting in 2018, the aim is none other than to improve services to the public. (Matvejciuk, L. ,2019).

Information Services at the Ministry of Finance are carried out, one of which is the HAI (Help, Answer, Improve) Contact Center service of the Directorate General of Treasury or known as DJPb HAI branding. As the management of information technology services, HAI DJPb performs a service desk function for service users of the Directorate General of Treasury, Ministry of Finance to submit service requests, questions, and problems regarding applications or regulations, policies, and business processes related to the treasury. HAI DJPb provides various communication channels for service users to contact HAI DJPb, including electronic mail/email 
Minhando, E., Sudarmo and Rahmanto, A. (2021), "Integrated contact center HAI (help, answer, improve) as information service innovation at the ministry of finance, Indonesia", Management and entrepreneurship: trends of development, 3(17), pp.27-42. Available at: https://doi.org/10.26661/2522-1566/2021-3/17-03.

(hai.djpb@kemenkeu.go.id), HAI DJPb web portal (https://hai.kemenkeu.go.id ), live chat, Call Center 14090, and also through social media Instagram, Twitter, and Facebook. (hi.kemenkeu.go.id, 2020)

Improving service quality is closely related to various forms of policy innovation in the Ministry of Finance's HAI information services. Innovation in public administration is a hot issue, especially in our country because it has been regulated in Government Regulation Number 38 of 2017 concerning Regional Innovation which in this regulation the government, in this case, has guaranteed every government agency to carry out various reforms in its implementation so that it can support the achievement of services. prime. Sedarmayanti stated that innovation includes the creation of something that does not exist today and can be a small creation of something monumental. (Sedarmayanti, 2009). Fuglsang \& Pedersen in Wicaksono (2018) also states that at least innovation is related to two things, namely: (1) doing something new and (2) developing something new that can run according to the context. Policy innovation here is innovation in implementing policies from the Center as well as developing by making new policies without leaving the existing policies on it. Policy innovation itself is a necessity to solve public problems that continue to develop in society so that it becomes one of the best alternatives in the long term to solve public problems and reduce the impact (Sururi, 2016). This article was written to describe the information service policy innovations in the HAI Contact Center of the Ministry of Finance. These forms of innovation are identified so that they can be used as a form of policy recommendations to continue in the future to improve the quality of public services through the Ministry of Finance's HAI.

\section{LITERATURE REVIEW}

The organization is a collaboration that is achieved symbolically, and organizational communication is a field that studies how cooperation is achieved or how the form of the organization is made. Organizations consist of a collection of individuals, and each organization has its characteristics that are different from one another. Organizations are built in different ways depending on the goals, attitudes, and principles of the organization. Organizational communication theory is a communication theory perspective seen from the level or level of communication (Littlejohn, 2017). Karl Weick uses communication as the basis of human organization and provides a rationale for understanding how people organize. According to this theory, organizations are created through communication activities, they are not structures made of positions and roles. (Littlejohn, 2017). Organize interactions and reason-making processes to reduce uncertainty over the information obtained. The presence of uncertainty, complications, ambiguity and lack of predictability is a form of uncertainty.

A critical approach to organizational communication is to describe, understand, explain and criticize how organizational communication is within an organization. (Miller, 2014). The existence of uncertainty over a system, environment, or within the scope of running an organization is a form of how to deal with environmental changes that cannot be avoided within the organization. While effective communication is one of the key factors in managing change within the organization. (Ziemba, E., \& Obłąk, I., 2015). According to Lewin (1951) in Robbin (1994) change occurs because of the emergence of pressures on organizations, individuals, or groups. Managing an organization is a challenge in a changing environment (uncertainty). Managing an organization is a challenge in a changing environment. Organizations must adapt to their environment to maintain or increase their effectiveness. So that organizations as developers of monitoring and feedback mechanisms to identify and follow their environment, sense changes in the environment, and make appropriate adjustments if necessary. Stephen Robbin (1994) proposed a model for managing organizational change. Starting from identifying whether the change is needed in the organization, what the changes are, to mapping the ways and results in the organization wants to achieve. Change is initiated by certain forces. This power is exercised within the organization by a change agent. The 
agent chooses his intervention action, meaning he chooses what to change, whether the structure, technology, process, organization, or everything to change.

Changes in one area of the organization are likely to generate new forces for other changes and make the organization more effective. Robbins defines more generally, namely organizational effectiveness. So, organizational change does not have to be specific to improve performance but is intended to increase the effectiveness of the organization in achieving the goals and objectives that have been set. Changes within the organization can encourage innovation within the organization. Fuglsang \& Pedersen (in Wicaksono, 2018) state that at least innovation is related to two things, namely: (1) doing something new and (2) developing something new that can run according to the context. According to Mulgan and Albury (in Khairul Muluk, 2008), the success of innovation is the creation and implementation of processes, service products, and service methods. Process innovation stems from the continuous quality improvement movement and refers to the combination of organizational changes, procedures, and policies required to innovate. While product or service innovation comes from changing the shape and design of the product or service. Innovation in service methods is a new change in terms of interacting with customers or a new way of providing services. In public sector innovation, Halvorsen, Hauknes, Miles, \& Rose (in Wicaksono, 2018) state that there are 6 typologies of public sector innovation, namely service product innovation, process innovation, administrative innovation, system innovation, conceptual innovation, and radical innovation.

An innovation that develops within the organization is also influenced by several factors, namely leadership (Leadership), management (Management/Organization), risk management (Risk Management), human resource capabilities (Human Capital), and technology (Technology). (Cook, Matthews, and Irwin in Grisna and Wawan. 2013). The innovation in this study discusses innovations about information services, so a form of urgency is needed about the importance of innovation in the development of information services for users. Information service is a sociotechnical phenomenon that involves humans and information technology (IT) to support the implementation of tasks and organizational performance, which aims to help someone obtain the information they need (Mathiassen \& Sorensen, 2007). This is also expressed by Winkel (2006) which explains that information service is a service that seeks to meet the individual's lack of information they need. Information services also mean efforts to equip participants with knowledge and understanding of their environment. Prayitno (2004) explains that the purpose of implementing information services is divided into two, namely, the general goal is to master certain information by service participants to be used for their needs (effective daily living), and special objectives related to understanding service information used for problem-solving (if the participant concerned experiences it). ); to prevent problems from arising, and to enable the participants concerned to open themselves up in actualizing their rights.

\section{PAPER OBJECTIVE}

It has been described that the flow of organizational change and the role of crisis communication in changing the organization's information service system is a form of organizational adaptive management resulting from information service innovation. So it is important to know the flow of innovation in organizations based on the theory of change in organizations. This article intends to identify and describe information service innovations to adapt to managing changes in the organizational environment. Based on the theory of change in organizations (Lewin, 1951) which responds to uncertainty (Miller, 2014) a form of information service innovation (Halvorsen, Hauknes, Miles, \& Rose) was developed that can facilitate organizational communication to improve the quality of service from the organization. 
Minhando, E., Sudarmo and Rahmanto, A. (2021), "Integrated contact center HAI (help, answer, improve) as information service innovation at the ministry of finance, Indonesia", Management and entrepreneurship: trends of development, 3(17), pp.27-42. Available at: https://doi.org/10.26661/2522-1566/2021-3/17-03.

\section{METHODOLOGY}

This article uses qualitative methods with descriptive analysis, and researchers use data triangulation techniques in collecting and analyzing existing data. The process of triangulation of data sources is carried out by collecting data from different sources which are then analyzed and compared. The validity of the data is obtained by comparing and cross-checking the data sources. The stages carried out by researchers in processing data were carried out in three stages. The first is observation, which is done by looking at and studying the object of research so that the focus of the research can be more easily studied and studied. The focus of this research is the Ministry of Finance's HAI information service innovation. Researchers make observations by looking at what forms of innovation exist in HAI integrated information services and try to identify the types of innovations that exist and the ongoing process of information services. Furthermore, the results of these observations are recorded and analyzed according to the data in the field or not. The second stage was interviewing, researchers conducted structured interviews with the leaders of the HAI Contact Center of the Ministry of Finance as well as several leaders related to integrated information services. In addition, unstructured interviews were also conducted as a further effort to obtain in-depth data, conducted on employees and users. The third stage is documentation as secondary data, which is needed to find out the track record of changes in information service policies and innovations that have been made in improving the service quality. The documentation obtained includes policy documents, service performance documents, and analysis results of HAI integrated information service performance reports.

\section{RESULTS AND DISCUSSION \\ 1. Description of HAI (Help, Answer, Improve) Integrated Information Services Innovation}

Policy in a system is a very important thing to pay attention to. The policy is the spearhead of how a system can exist and run well. In a public sector service organization, of course, the policies taken must be following the order of the policies above. Every internal policy of the organization may make a breakthrough in the implementation of the central policy so that a companion policy emerges for a form of innovation to be carried out to improve its performance. According to Chrusciel, D., \& Field, D. W. (2006) there are two critical success factors through transformational change, namely, there is a flexible organizational policy (comprehensive regarding the needs of the organization), and the organization can accommodate the personal needs of the change actors to suit the needs of the organization. Of course, this organizational policy is made to take into account the many interests of various sectors. The Ministry of Finance is one of the public sector organizations engaged in finance, which is a central element in state administration which includes state revenues and expenditures. This is a demand for the Ministry of Finance to provide effective and efficient services. The existence of demands to maintain the integrity of public services makes innovations continue to be carried out to meet what is expected by the community. The success of an innovation is indicated by a significant increase in the efficiency and effectiveness of the service. The definition of innovation in the field of public services is a creative idea of technology or new ways in service technology or updating existing ones in the field of service technology or creating breakthroughs or simplifications in the fields of rules, approaches, procedures, methods, or service organizational structures whose benefits have added value. both in terms of quantity and quality of service. (Kurniasari \& Sulandari, 2017)

There are types of innovation that can serve as a benchmark for how innovation can be built within an organization. According to Mulgan and Albury that the success of innovation is the creation and implementation of the first is a process, namely successful innovation is the creation and implementation of the process. (Muluk, K., 2008). While process innovation originates from the continuous quality renewal movement and refers to the combination of organizational changes, 
procedures, and policies required to innovate. The second innovation is service products, namely product or service innovations derived from changes in the shape and design of products or services. The third is service method innovation, namely innovations in terms of interacting with customers or new ways of providing services.

At the Ministry of Finance, process innovation is implemented, among others, in the form of changes in organizational management, both in the management of Human Resources, Administration and Organization, Information Systems, Supervision, and Accountability. Of course, the change process itself cannot run immediately, some stages must be passed in the change process. According to Kurt Lewin, the change process itself has gone through three stages of change starting from melting, moving, and freezing again. (Robbins, 2007). The change process itself is in the Ministry of Finance starting from the socialization of the new policy, there are conflicts and rejections until finally there is a form of acceptance because of the new policy. The entire process of change must be passed so that there is innovation in terms of policies and procedures. (Ningtyas, T, 2020). The existence of this form of change makes the organization more developed by the demands of the community for better services. The business process is one of the illustrations to see how the organization moves according to its system, whether it is receiving technical assistance or not. As part of this organizational change process, information services are very crucial in an organization, this is because the information service system is in the face of the service of a public organization.

Information services continue to grow and are dynamic in line with advances in information technology. Various information technology platforms provide various things that can be used as a means of providing information services for public organizations to all stakeholders. Information services are used as a source of prudent information to users and stakeholders related to regulations and business processes at the Ministry of Finance. Information Services at the Ministry of Finance are carried out, one of which is the HAI (Help, Answer, Improve) Contact Center service of the Directorate General of Treasury or known as Directorate General of Treasury (DJPb) HAI branding. The scope of HAI is all services related to regulations, business processes, and troubleshooting applications/tools related to payment of state expenditure bills submitted by the Budget User Authority (KPA) at the Ministry/Agency to the Ministry of Finance as the State General Treasurer (BUN). Below will be described the information service business processes that existed within the Ministry of Finance before the information service system innovation.

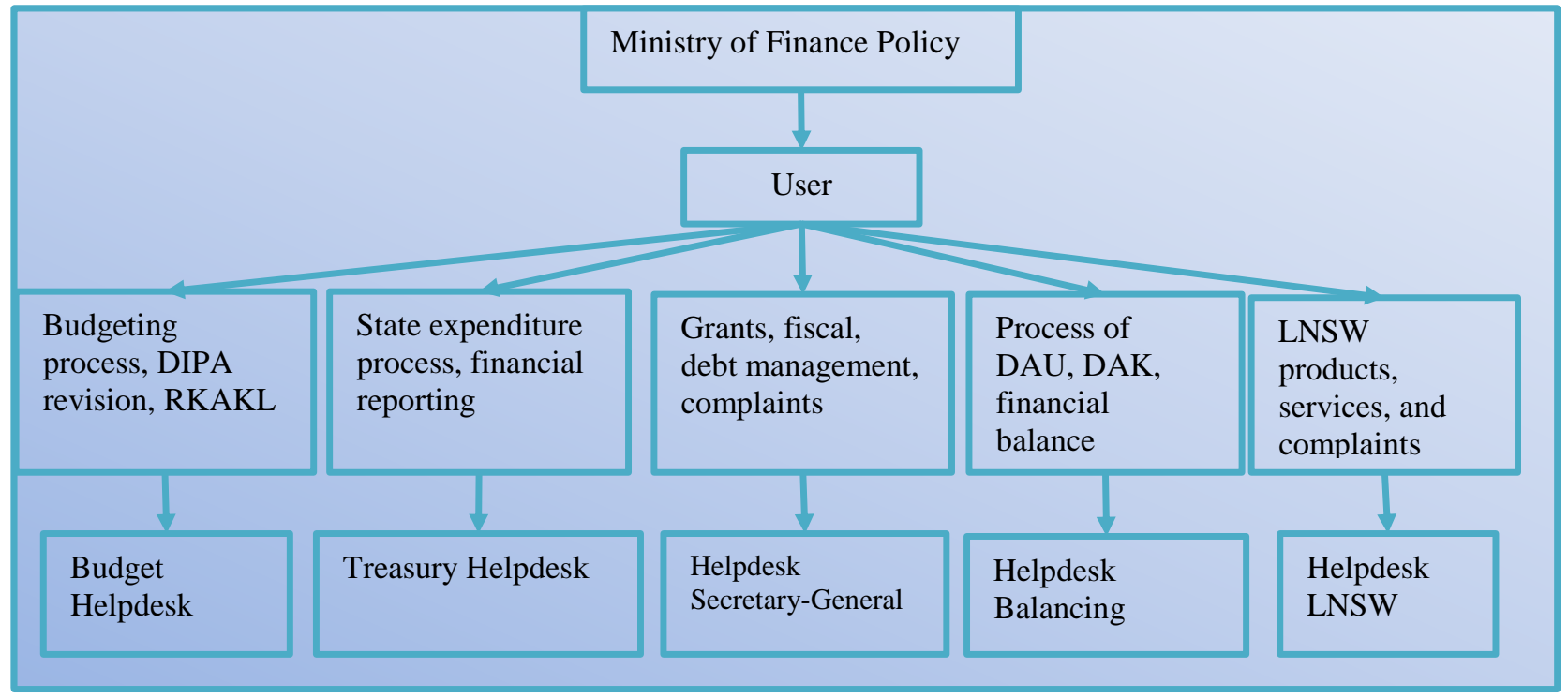

Figure 3 Information Service Flow before innovation

Source: own compilation 
Minhando, E., Sudarmo and Rahmanto, A. (2021), "Integrated contact center HAI (help, answer, improve) as information service innovation at the ministry of finance, Indonesia", Management and entrepreneurship: trends of development, 3(17), pp.27-42. Available at: https://doi.org/10.26661/2522-1566/2021-3/17-03.

Figure 3 above can be seen that the information service system of the ministry of finance is still being implemented partially. This resulted in a lot of information not reaching the user so that the problem of filing, disbursing, and reporting the state budget also encountered an obstacle. The existence of a separate system creates irregular communication patterns that are considered difficult and even considered ineffective in managing information within the organization. As a result, many services to users are hampered because the information obtained by users is not following what is expected. In addition, organizational efficiency is also an important consideration in the information service business process as shown in Figure 1. Efficiency is not found in the structure, so there is a need for a form of innovation to increase the effectiveness and efficiency of the organization. The number of activities related to information services that are considered inefficient has been cut down when there is a DJPb HAI information service system with spaces that can accommodate the needs of existing information services. Below is a picture of the flow of DJPb HAI information services related to treasury services at the Ministry of Finance.

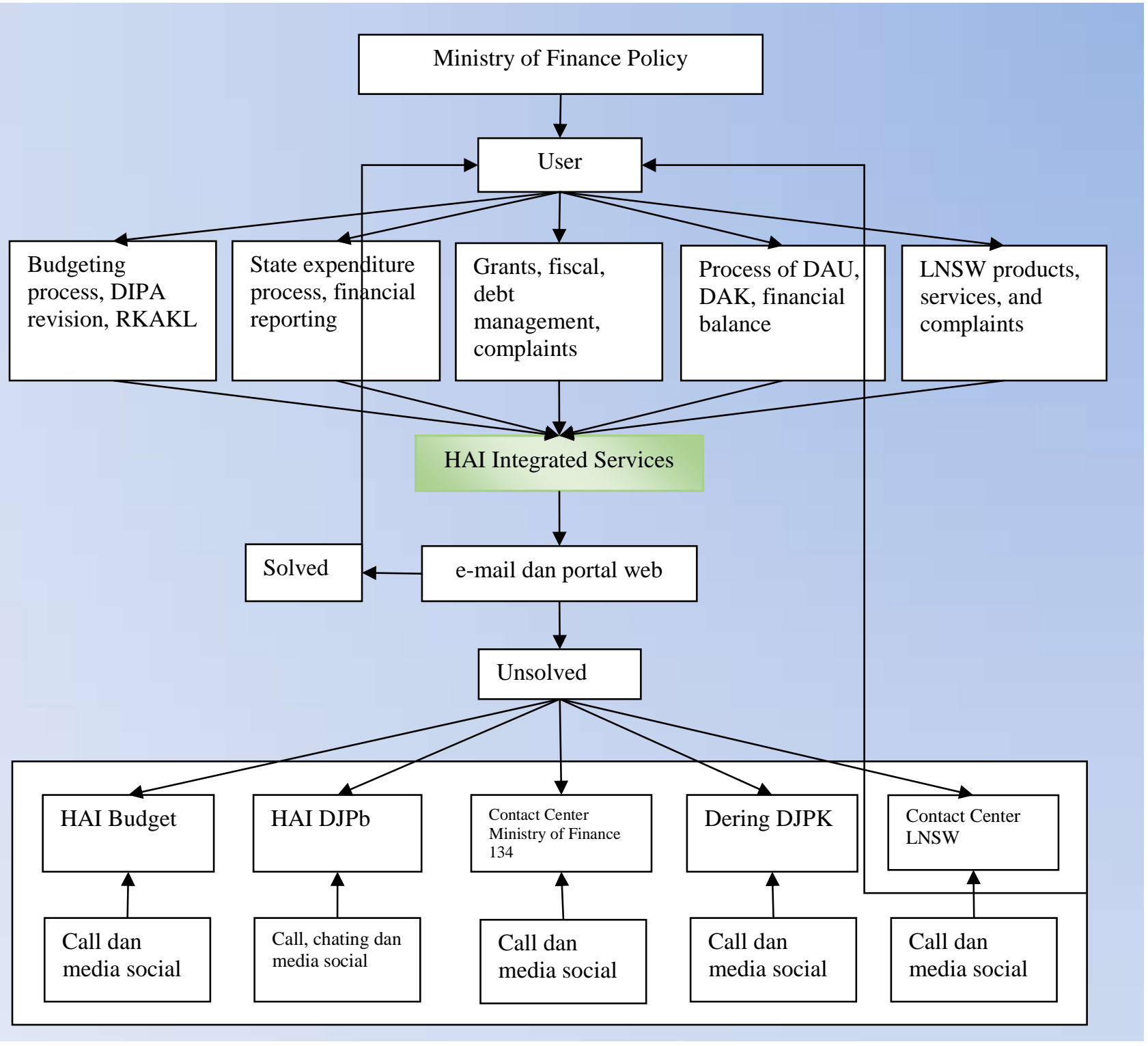

Figure 4 HAI Integrated Information Service Flow

\section{Source: own compilation}

Based on the illustration in Figure 4 above, it can be seen that the flow in the service process does require a lot of time if technology is not used that can simplify the whole process. So that work 
units and stakeholders can receive many benefits from the development of technology and information systems in service policies at the Ministry of Finance. The information service system developed in this integrated service is intended to develop a one-stop user information service system. So that all requests for information submitted to the Ministry of Finance will be included in the HAI integrated information service.

The flow is that if the incoming information request can be completed on the layer one agent in the integrated service, the answer will be directly submitted to the user. However, if the information requested by the user is not available at the layer 1 agent, it will be forwarded to the layer 2 agents consisting of HAI Budget, HAI DJPb, Contact Center Ministry of Finance 134, Dering DJPK (Directorate General of Fiscal Balance), and CC Single Window National Institute (LSNW) to be answered and forwarded to the user. The entire development of this system is also followed by the development of existing technology and resources. The development of information systems and technology is a door that cannot be separated from the contact center information service system. (Park, J. et al, 2011). The development of information systems through the use of these technologies is a form of system innovation. The innovation in this system is an existing process innovation through a policy on HAI integrated information services, meaning that all information services at the Ministry of Finance will be managed integratively by the HAI contact center. The second innovation is product innovation, product innovation in financial implementation services is the design of service products as part of the effectiveness of work, one of which is innovation to create a structured system and make it easier to use so that the value of the benefits is greater.

\section{HAI (Help, Answer, Improve) Integrated Contact Center Service Products}

HAI's Contact Center service continues to grow along with the development of information technology. Starting to officially operate in 2016, the HAI Contact Center service, which initially provided information services and problems related to state spending, is currently also used as a helpdesk for service products, policies, grants, fiscal, debt management, General Allocation Funds, Funds Special Allocations, financial balance, budgeting and complaints from the Ministry of Finance as well as services, products, and complaints within the National Single Window Institution. HAI Contact Center service products and HAI service developments are mentioned in table 1 below:

Table 1 above shows that there are many product innovations produced by the Ministry of Finance to improve the performance of the services provided. The product is of course made by taking into account the binding regulations in it. This illustrates that the policy innovations formed by the existence of these products have been made through a legal process. The third innovation is the method, in general, it can be seen that the service method is very well developed which of course the previous method had a traditional concept using minimal technology and had to go through many bureaucratic processes to shift to become more systematic and effective by utilizing and developing technology according to the needs of the community. organization. Talking about the importance of IT management in public sector organizations. IT is very useful in the process of achieving organizational goals, strategic planning, HRM, and risk management. In addition, the management system, human resources, supervision, and accountability can be part of the main innovations produced in this organization. (Amali, et al, 2014). 
Minhando, E., Sudarmo and Rahmanto, A. (2021), "Integrated contact center HAI (help, answer, improve) as information service innovation at the ministry of finance, Indonesia", Management and entrepreneurship: trends of development, 3(17), pp.27-42. Available at: https://doi.org/10.26661/2522-1566/2021-3/17-03.

Table 1

\section{HAI Contact Center Service Products}

\begin{tabular}{|c|c|c|c|}
\hline No & Year & Product Name & Description \\
\hline 1 & 2016 & $\begin{array}{l}\text { Helpdesk } \quad \text { Integrated } \\
\mathrm{HAI} \text { DJPb }\end{array}$ & $\begin{array}{l}\text { Information delivery services as well as problems } \\
\text { related to state spending, the media used through } \\
\text { email and chat services }\end{array}$ \\
\hline 2 & 2017 & HAI-Call 14090 & $\begin{array}{l}\text { Service delivery of information and problems by } \\
\text { telephone to number 14090, either inbound or } \\
\text { outbound }\end{array}$ \\
\hline 3 & 2018 & HAI CSO & $\begin{array}{l}\text { HAI services that are integrated with vertical office } \\
\text { units throughout Indonesia, both Provinces and } \\
\text { Districts/Cities }\end{array}$ \\
\hline 4 & 2018 & HAIPEDIA & $\begin{array}{l}\text { Web-based Management System that summarizes } \\
\text { all the problems and solutions that have been } \\
\text { submitted through HAI }\end{array}$ \\
\hline 5 & 2019 & HAI TALK & $\begin{array}{l}\text { Talkshow program through Live IG with the theme } \\
\text { of education related to treasury }\end{array}$ \\
\hline 6 & 2020 & $\begin{array}{l}\text { Contact Center Ministry } \\
\text { of Finance } 134\end{array}$ & $\begin{array}{l}\text { Helpdesk service products, policies, grants, fiscal, } \\
\text { debt management, and complaints from the } \\
\text { Ministry of Finance by telephone to Call Center } \\
\text { number } 134\end{array}$ \\
\hline 7 & 2020 & Dering DJPK & $\begin{array}{l}\text { Helpdesk products, policies, and complaints } \\
\text { regarding General Allocation Funds, Special } \\
\text { Allocation Funds, and others regarding financial } \\
\text { balance }\end{array}$ \\
\hline 8 & 2020 & HAI Budget & $\begin{array}{l}\text { Helpdesk products, policies, and complaints } \\
\text { related to the budgeting process, revision of DIPA, } \\
\text { RKAKL, Simponi application, Satu DJA, and } \\
\text { Sakti Budget. }\end{array}$ \\
\hline 9 & 2020 & $\begin{array}{l}\text { Contact Center National } \\
\text { Single Window } \\
\text { Institute (LNSW) }\end{array}$ & $\begin{array}{l}\text { Helpdesk products, services, and complaints } \\
\text { related to the scope of services of the National } \\
\text { Single Window Lembaga }\end{array}$ \\
\hline
\end{tabular}

Source: HAI Document, 2020

The following are innovations in the IT field that were generated in the process of change in the Ministry of Finance's HAI Contact Center service

Figure 5 above shows that many product developments exist as part of policy innovation in the Ministry of Finance's HAI Contact Center service. Of course, this is inseparable from the existence of a lot of support from internal organizations that are committed to changing the organization for the better. The existence of technology can certainly ease human tasks, as well as the existence of technology in the Ministry of Finance can reduce employee performance and of course, it is more efficient and cheaper in terms of costs. Another type that is now also developing is innovation in system interaction which includes new or updated ways of interacting with other actors or in other words changes in governance. Like how the management relates to the community in terms of socializing the many changes. 


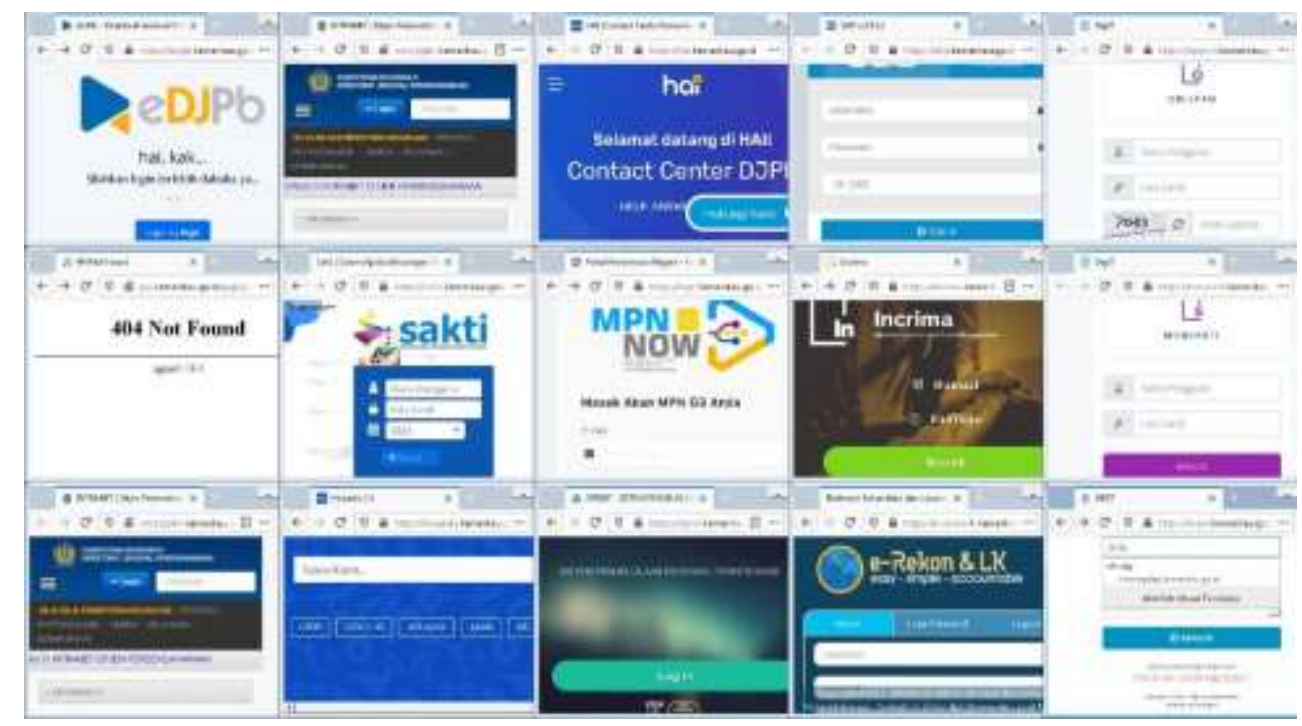

Figure 5 HAI Contact Center Innovation Products of the Ministry of Finance

\section{Source: HAI Document, 2020}

There are at least 6 typologies of public sector innovation, Halvorsen, Hauknes, Miles, \& Rose, in Wicaksono (2018) stating that the first is the creation of a new service or the development of a service. The second is a process innovation that emphasizes changing how a particular service or product is produced. The third is administrative innovation that focuses on policy change. Fourth is system innovation, namely changes in the organizational structure or changing the way of cooperation and interaction within the organization. For example, streamlining the organizational structure or the leadership of the organization delegating authority to certain units within the organization. Fifth is conceptual innovation, namely a change in the perspective of the actors involved so that it is more comprehensive in solving problems.

\section{HAI (Help, Answer, Improve) Integrated Information Service Innovation Typology}

At the Ministry of Finance, apart from the process, product, and method innovations, there are also system and conceptual innovations. System innovation at the HAI Contact Center is realized by changes to the existing system, starting from policies, restructuring to how to conduct advocacy and socialization to users. Restructuring is carried out to regenerate and trim positions that are considered overlapping with other positions and add structure if needed to strengthen the change agenda, mostly in the technology sector. Previously, each unit had separate service desk services, with the HAI Contact Center, service desk services are integrated and can be measured in real-time. In addition, conceptual innovation is even more interesting to do a form of more in-depth analysis. Conceptual innovation in the HAI Contact Center is an important part of the change process, this is because it intersects with the principles and perspectives of organizational members. In addition, the commitment to change and focus on making innovative policies and implementing them well to improve public services is a separate note. Great leadership commitment and the support system that is around it make all stakeholders can well accept this form of service system change. The change in perspective from the traditional to the modern and IT-based is the biggest form of policy innovation in the organization. In addition, the form of transparency of information to users is a form of good innovation in the process of managing public organizations. This transparent principle is also supported collaboratively so that the policies taken are acceptable and represent all the needs of the users. Table 2 below can describe the identification of all policy innovations in the HAI Contact Center of the Ministry of Finance. 
Minhando, E., Sudarmo and Rahmanto, A. (2021), "Integrated contact center HAI (help, answer, improve) as information service innovation at the ministry of finance, Indonesia", Management and entrepreneurship: trends of development, 3(17), pp.27-42. Available at: https://doi.org/10.26661/2522-1566/2021-3/17-03.

Table 2

Service innovation at HAI Contact Center

\begin{tabular}{|c|c|}
\hline Criteria & Forms of Policy Innovation \\
\hline $\begin{array}{l}\text { Process } \\
\text { innovation }\end{array}$ & $\begin{array}{l}\text { The use of technology in the administrative process starting from } \\
\text { submitting complaints or requests for information services to feedback by } \\
\text { service providers is also carried out online } \\
\text { Changes in business processes of all services provided by the Ministry of } \\
\text { Finance }\end{array}$ \\
\hline $\begin{array}{l}\text { Method } \\
\text { innovation }\end{array}$ & $\begin{array}{l}\text { Use of technology and online-based services and make it easier for users } \\
\text { Use of modern media that can be easily accessed by users (chat, social } \\
\text { media, etc.) }\end{array}$ \\
\hline $\begin{array}{l}\text { Product } \\
\text { innovation }\end{array}$ & $\begin{array}{l}\text { There are various innovative products created that are informative and easy } \\
\text { to understand by users. } \\
\text { Develop application products to make it easier for users to access and } \\
\text { obtain information related to the state budget }\end{array}$ \\
\hline $\begin{array}{l}\text { System } \\
\text { Innovation }\end{array}$ & There is restructuring to improve organizational performance \\
\hline $\begin{array}{l}\text { Conceptual } \\
\text { innovation }\end{array}$ & $\begin{array}{l}\text { Changing the perspective of service from traditional to modern and based } \\
\text { on Technology and Information. }\end{array}$ \\
\hline
\end{tabular}

Source: own compilation

In table 2 above, it can be seen that there have been five types of innovations in HAI integrated information service policies identified. The five types run complementary to each other and develop periodically to improve the innovative products that have been produced. This information service innovation can be used as a form of reference on the use of technology in the egovernment approach to satisfy users in providing information services for state financial services.

\section{CONCLUSION}

This study shows that there are five types of innovations in information service innovation at the HAI Contact Center of the Ministry of Finance to improve service quality. The five innovations are process innovation, method innovation, product innovation, system innovation, and conceptual innovation. Process innovation can be seen in the innovation of all business processes in budget services, method innovation is seen from the shift in the tools used for services from manual to technology-based. Product innovation with the launch of many innovative products to support the effectiveness and efficiency of treasury services. System innovation can be seen in organizational restructuring to follow organizational goals in improving service performance. Conceptual innovation can be seen in changes in the perspective of stakeholders in responding to changes for the better. Each type of innovation is developed according to the portion and needs of the organization. These policy innovations exist through a process of change so that they come to the form of new policies and their implementation to improve the quality of information services at the HAI Contact Center of the Ministry of Finance.

\section{REFERENCES}

Amali, L. N., Mahmuddin, M., \& Ahmad, M. (2014). Information technology governance framework in the public sector organizations. Telkomnika, 12(2), 429. http://doi.org/10.12928/TELKOMNIKA.v12i2.1834 
Chrusciel, D., \& Field, D. W. (2006). Success factors in dealing with a significant change in an organization. Business Process Management Journal. https://doi.org/10.1108/14637150610678096

Dokumen HAI Kementerian Keuangan, 2020.

Grisna Anggadwita dan wawan Dhewanto. Tahun 2013. Inovasi Layanan di Sektor Publik: Studi Kasus pada PT. Kereta Api Indonesia. Jurnal Sosial dan Ilmu Pembangunan Vol. 4, No. 7, 2013.

Islamy, M. Irfan. 2009. Prinsip-prinsip Perumusan Kebijaksanaan Negara. Jakarta: Bumi Aksara.

Kickert, W. J. (2014). Specificity of change management in public organizations: Conditions for successful organizational change in Dutch ministerial departments. The American Review of Public Administration, 44(6), 693-717. https://doi.org/10.1177/0275074013483871

Kuipers, B. S., Higgs, M., Kickert, W., Tummers, L., Grandia, J., \& Van der Voet, J. (2014). The management of change in public organizations: A literature review. Public administration, 92(1), 1-20. https://doi.org/10.1111/padm.12040

Kurniasari, H., \& Sulandari, S. 2017. Inovasi Pelayanan Publik di Balai Pelayanan Penempatan dan Perlindungan Tenaga Kerja Indonesia (BP3TKI) Semarang. Journal of Public Policy and Management Review. 6(2), 545-564.

Laporan Tahunan Ombudsman RI. $2016 \quad-\quad 2020 . \quad$ Laporan Tahunan. https://ombudsman.go.id/produk?c=19\&s=SUB_LT 5a1ea951d55c4

Littlejohn, S. W., Foss, K. A., \& Oetzel, J. G. (2017). Theories of Human Communication. 11th Editions.

Mathiassen, L., \& Sørensen, C. (2007). A theory of organizational information services. LSE, Department of Management, Information Systems Group.

Matvejciuk, L. (2019). Public administration in the conditions of the development of digital economy and society. Management and entrepreneurship: trends of development, 2(08), 7787. https://doi.org/10.26661/2522-1566/2019-2/08-07

Miller, K., \& Barbour, J. (2014). Organizational communication: Approaches and processes. Cengage Learning.

Muluk, K. (2008). Knowledge Management: Kunci Sukses Inovasi Pemerintah Daerah. Malang: Bayumedia Publishing 45)

Muluk, K. (2008). Knowledge Management: Kunci Sukses Inovasi Pemerintah Daerah. Malang: Bayumedia Publishing.

Ningtyas, T (2020). Describe changes management system for a public organization in Indonesia (Case study of bureaucracy innovation at margono hospital purwokerto) Proceedings of the 5th NA International Conference on Industrial Engineering and Operations Management, IOEM 2020; Virtual; United States; 10 August 2020 through 14 August 2020; Code 144118 http://www.scopus.com/inward/record.url?eid=2-s2.085096578907\&partnerID=MN8TOARS

Ningtyas, T. (2017). New Public Service: Pelayanan Publik Berbasis Humanistik untuk Kesuksesan Reformasi Birokrasi. Jurnal Ilmiah Manajemen Publik dan Kebijakan Sosial, 1(1), 13-22 https://doi.org/10.25139/jmnegara.v1i1.283

Osborne dan Gaebler 1992, reinventing Government: how to the entrepreneur spirit is transforming the public service, alih bahasa abdul roshid, PPM:Jakarta

Parasuraman A, Grewal D. The impact of technology on the quality-value-loyalty chain: a research agenda. Acad Mark Sci 2000;28(1):168-74. https://doi.org/10.1177/0092070300281015

Park, J., Chung, H., \& Rutherford, B. (2011). Social perspectives of e-contact center for loyalty building. Journal of Business Research, 64(1), 34-38. https://doi.org/10.1016/j.jbusres.2009.09.017 
Minhando, E., Sudarmo and Rahmanto, A. (2021), "Integrated contact center HAI (help, answer, improve) as information service innovation at the ministry of finance, Indonesia", Management and entrepreneurship: trends of development, 3(17), pp.27-42. Available at: https://doi.org/10.26661/2522-1566/2021-3/17-03.

Patrickson, M., \& Bamber, G. (1995). Introduction. In M. Patrickson, V. Bamber, \& G. Bamber (Eds.), Organisational Change Strategies, Case Studies of Human Resource and Industrial Relations Issues. Melbourne: Longman

Prayitno. 2004. Layanan Bimbingan Kelompok Konseling Kelompok. Padang : Universitas Negeri Padang.

Rees, C. J., Hassard, J., \& Yonnedi, E. (2010). Privatization, organizational change and performance: evidence from Indonesia. Journal of Organizational Change Management. https://doi.org/10.1108/09534811011071234

Rijo, R., Varajão, J., \& Gonçalves, R. (2012). Contact center: information systems design. Journal of Intelligent Manufacturing, 23(3), 497-515. https://doi.org/10.1007/s10845-010-0389-0

Robbin, Stephen P, (1994). Teori Organisasi: struktur, desain dan aplikasi, edisi 3, alih bahasa, Jusuf Udaya, Jakarta,

Robbin, Stephen P, (2007). Perilaku organisasi, edisi kesepuluh, alih bahasa, Benyamin Molan, Indeks, Indonesia,

Robbins, S. P., \& Udaya, J. (1994). Teori Organisasi: struktur, desain, dan aplikasi.

Sedarmayanti, 2009. Reformasi Administrasi Publik, Reformasi Birokrasi, dan Kepemimpinan Masa Depan. Bandung: Refika Aditama.

Sheefeni, N., \& Mutingil M. (2016). An Assessment of Service Quality Delivery in Selected Local Authorities in Namibia.

Soekardi, A., Indrawati, R., \& Erni, N. (2020). The influence of communication skill toward employee performance in radiology installation unit of hospital. Management and entrepreneurship: trends of development, 4(14), 31-42. https://doi.org/10.26661/2522$1566 / 2020-4 / 14-03$

Sururi, A. (2016). Inovasi Kebijakan Publik (Tinjauan Konseptual dan Empiris). Sawala: Jurnal Administrasi Negara, 4(3). https://doi.org/10.30656/sawala.v4i3.241

Welch. Wong, (1998). Earning Mangement and thelong run under performance of initial Public offering, Journal of Finance, https://doi.org/10.1111/0022-1082.00079

Wicaksono, K. W. (2018). Tipologi Inovasi Sektor Publik Pada Tiga Program Inovatif Pemerintah Daerah Kota Surabaya (Tinjauan Reflektif Terhadap Tiga Inovasi Pelayanan Publik Pemerintah Kota Surabaya Tahun 2018). Jurnal Manajemen Pelayanan Publik, 1(2), 196-205 https://doi.org/10.24198/jmpp.v1i2.19895

Winkel \& Hastuti. 2006. Bimbingan dan Konseling di Institusi Pendidikan. Media Abadi, Yogyakarta.

Worrall, L., Cooper, C., \& Campbell, F. (2000). The impact of organizational change on UK managers' perceptions of their working lives. The organization in crisis: Downsizing, restructuring, and privatization, 20-43.

Yeatman, A. (1994). The reform of public management: an overview. Australian Journal of Public Administration, 53(3), 287-295.

Ziemba, E., \& Obłąk, I. (2015). Change management in information systems projects for public organizations in Poland. Interdisciplinary Journal of Information, Knowledge, and Management, 10, 47-62 http://www.ijikm.org/Volume10/IJIKMv10p047-062Ziemba1527.pdf

\section{ІНТЕГРОВАНИЙ КОНТАКТНИЙ ЦЕНТР НАІ (ДОПОМОГА, ВІДПОВІДІ, ПОКРАЩЕННЯ) ЯК ІНФОРМАЦЙНА СЛУЖБА ІННОВАЦІЙ У МІНІСТЕРСТВІ ФІНАНСІВ, ІНДОНЕЗІЯ}

Erys Al Fauzi Minhando

Universitas Sebelas Maret Surakarta, Central Java, Indonesia

\section{Sudarmo}

Universitas Sebelas Maret

Surakarta, Central Java, Indonesia
Andre Noevi Rahmanto

Universitas Sebelas Maret

Surakarta, Central Java, Indonesia

Метою статті є виявлення та опис інновацій в сфері інформаційних послуг, що існують 
в Міністерстві фінансів в Індонезії. Використовуючи якісні методи з описовим аналізом, це дослідження описує і пояснює існування цих нововведень. В рамках цього дослідження були проведені інтерв'ю з керівниками, пов'язаними з інноваціями інформаційних послуг Контактцентру HAI, і співробітниками, які обіймають керівні посади в управлінні інноваційними проектами. В ході написання статті також досліджується динаміка змін в впровадженні інновацій в системах інформаційних послуг, що існують в організації. Це дослідження показує, що в Контактному центрі HAI Міністерства фінансів існує п'ять типів інновацій в сфері інформаційних послуг, спрямованих на підвищення якості обслуговування, а саме: процесні інновації, продуктові інновації, методичні інновації, системні інновації та концептуальні інновації. Використання даної типології забезпечує прогрес в поліпшенні якості обслуговування в контакт-центрі НАI.

Ключові слова: політика інновацій, комунікаційні послуги, інформаційні технології.

\section{ИНТЕГРИРОВАННЫЙ КОНТАКТНЫЙ ЦЕНТР НАІ (ПОМОЩЬ, ОТВЕТЫ, УЛУЧШЕНИЯ) КАК ИНФОРМАЦИОННАЯ СЛУЖБА ИННОВАЦИЙ В МИНИСТЕРСТВЕ ФИНАНСОВ, ИНДОНЕЗИЯ}

\section{Erys Al Fauzi Minhando \\ Universitas Sebelas Maret \\ Surakarta, Central Java, Indonesia}

\author{
Sudarmo \\ Universitas Sebelas Maret \\ Surakarta, Central Java, \\ Indonesia
}

\author{
Andre Noevi Rahmanto \\ Universitas Sebelas Maret \\ Surakarta, Central Java, \\ Indonesia
}

Целью статьи является выявление и описание инноваций в сфере информационных услуг, существующих в Министерстве финансов в Индонезии. Используя качественные методы с описательным анализом, это исследование описывает и объясняет существование этих нововведений. В рамках этого исследования были проведены интервью с руководителями, связанными с инновациями информационных услуг Контакт-центра НАI, и сотрудниками, которые руководят инновационными проектами. В ходе исследования также исследуется динамика изменений в внедрении инноваций в системах информационных услуг, существующих в организации. Это исследование показывает, что в Контактном центре HAI Министерства финансов существует пять типов инноваций в сфере информационных услуг, направленных на повышение качества обслуживания, а именно: процессные инновации, продуктовые инновации, методические инновации, системные инновации и концептуальные инновации. Использование данной типологии обеспечивает прогресс в улучшении качества обслуживания в контакт-центре НАI.

Ключевые слова: политика инноваций, коммуникационные услуги, информационные технологии. 